\title{
INNOVATION IN CRIMINAL POLICY OF IMPOSING ALTERNATIVE SANCTIONS IN SLOVAK JUSTICE
}

\author{
Veronika Tóthová ${ }^{1}$, Simona Ferenčíková $^{2}$
}

\begin{abstract}
Concept of alternative sanctions imposition is based on principal ideas of so called restorative justice. Fundamental theses of restorative justice have been reflected in the Slovak legislation upon the adoption of applicable criminal- law regulation, namely through the development of the system of so called alternative sanctions vs short-term sanctions of imprisonment. This category of sanctions includes home confinement as a central topic of the article. The sanction of home confinement has passed major changes since its establishment. Material-law terms of such sanction imposition and its essence have gradually changed upon effect of legislation tools. The article provides for analysis of home confinement sanction imposition terms pursuant to the Penal Act in the context of application issues that have been identified, concurrently searching for causes of low frequency of such sanction imposition from the statistical data analysis. Furthermore, the article points to significant application problems of home confinement execution associated with the probation officers institute and monitoring of the sanction execution by technical means that can be considered innovative in the area of sanction execution monitoring. In its final section, the article offers detailed analysis of draft legislation related to the terms of home confinement sanction imposition and execution, as well as the range of criminal acts that can be punished with home confinement. Accordingly, the article presents considerations of possible effects of the proposed regulation on the decision-making judicial praxis. This article is aimed at analyzing the essence and purpose of home imprisonment sanction, the terms of its imposition, application of technical means to control the imprisonment in the context of application praxis issues, as well as evaluating the proposed legal regulation that changes principal terms of home imprisonment sanction imposition and its effects on decision-making and the application praxis.
\end{abstract}

UDC Classification: 4.1 .4 3/34, DOI: 10.12955/cbup.v7.1435

Keywords: Alternative Punishment, Home Prison, Probation Officer, Technical Check.

\section{Introduction}

The Slovak law system received suggestion to establish the restorative justice elements on the turn of the millennia especially in the penal law area. As we know, restorative justice represents the opposite to repressive justice, accentuating primarily the correction of affected subject (victim) harm caused by the perpetrator during the criminal act commitment. Alternative sanction can be marked as one of possibilities of restorative justice purpose fulfillment. Alternative sanctions have already existed in criminal law in the past, but their use has been limited (Gábriš and Jáger, 2018, 2019).

Development of alternative sanctions had been inspired mainly by Western European countries (mainly by Germany) as well as various recommendations made on the ground of EU bodies; we can include EU Council recommendations therein, related to criminal matters with reflected need for engagement in criminal proceedings the subject damaged along with the perpetrator. The resolution of the UN Committee of Criminal Prevention and Criminal Justice represented another important suggestion in 2002, containing a document on fundamental principles of restorative justice programs application to criminal matters (Strémy and Klátik, 2018). Moreover, alternative sanctions are applicable also in the European Union context, namely by mechanism of mutual recognition of judicial decisions in criminal matters (Klimek, 2017a, 2017b).

Gradual introduction of alternative sanctions and the approval of the Probation and Mediation Officers Act dated 2003, and the approval of the Mediation Act in 2004 implementing mediation directly in the Slovak legislation, represented strengthening of restorative justice. We can state that a broad spectrum of alternative sanctions can be currently found in the Penal Code that results from the sanction policy concept called restorative justice. Sanctions as a form of criminal-law sanctions are enumeratively contained in $\S 32$ of the Penal Code, being an expression of the fundamental sanctioning principle called nulla poena sine lege; this principle results also from Article 49 of the Slovak Constitution. Amongst the sanctions contained in $\S 32$ of the Penal Code, home confinement, due work order, monetary sanction and restricted participation on public events can be considered as alternative sanctions (Romža et al., 2018).

Home confinement penalty can be considered one of the most significant alternative sanctions that was enacted in the Penal Code in 2006 and passed extensive modifications up to the currently valid Penal

\footnotetext{
${ }^{1}$ Pavol Jozef Šafárik University in Košice, Faculty of Law, Košice, Slovak Republic. veronika.tothova@upjs.sk

${ }^{2}$ Pavol Jozef Šafárik University in Košice, Faculty of Law, Košice, Slovak Republic,

simona.ferencikova@upjs.sk
} 
Code. The home imprisonment sanction imposition and execution control has become a major innovation in this area. Before the end of 2015, the home imprisonment sanction execution had been allowed only by the probation officers. They were so called random personal checks. Significant change was introduced upon adoption of new legislation that enabled control of home imprisonment sanction execution by technical means. The stated institute is known from other countries' legislations along with Slovakia under the name electronic monitoring. Concurrently, technical means have been used in application of other institutes of proprietary law or procedural law.

Introduced technical control of home imprisonment execution was primarily aimed at increasing frequency of home imprisonment sanction imposition as an alternative sanction. Based on the latest statistical data, we can state that the precondition has not been met.

Despite of the existence of numerous professional periodical and special literatures focused on alternative sanctions, their essence, meaning, and the terms of their imposition and execution, only a small percentage deals with technical control of home imprisonment execution.

Accordingly, the article authors decided to analyze legislation in effect dealing with home imprisonment sanction, technical control of home imprisonment execution, and separately proposed the legal regulation that should expand the possibilities of technical means utilization. Based on the analysis, the authors shall make an effort to formulate the conclusion whether the lawmaker's efforts are correct.

The article in question is aimed at analyzing the essence of home imprisonment sanction as a type of alternative sanction, and at specifying its purpose. A subsequent goal is to analyze in detail the terms of home imprisonment sanction imposition from the proprietary law point of view, and evaluate the status de lege lata. This is followed by the analysis of proposed regulation of the terms of home imprisonment sanction imposition, i.e. another partial goal represents evaluation of the stated proposed changes. Therein, the authors shall point out the imperfections of the proposed regulation also in the context of application praxis that includes application of technical means to the home imprisonment sanction control. Last but not least, the article is aimed at formulating its own proposals de lege ferenda.

\section{Methodology}

Considering the methodology approach, analytic- synthetic methodology was primarily applied in the presented article in order to theoretically analyze the existing legal status, legal documents, comments, and expert opinions, and to formulate conclusions and proposals de lege ferenda upon concurrent application of scientific abstraction. In the context of the implementation of the new punishment concept in the Slovak legislation and foreign legislations, a historical - legal method was applied to the examination of historical law aspects and perception of the subject matter since the beginning of its evolution (Gábriš and Jáger, 2016). Moreover, a comparative method was used in the article for the purpose of comparison of foreign home imprisonment sanction regulations that findings can be drawn from and applied to the Slovak legal conditions, and for the purpose of comparing domestic regulation de lege lata to the proposed regulation of home imprisonment sanction imposition terms. The application of the description method is also irreplaceable for the description of further existing findings processing. Along with these methods, methods and practices used in scientific work were applied for the preparation of the subject matter - e.g. deduction, induction, analogy, abstraction, principles of formal logic, methods of law standards interpretation, and partial mathematical statistical methods.

\section{Home confinement penalty - state de legelata}

Home confinement penalty was re-enacted in the Slovak legislation upon re-codification of Act No. 300/2005 Coll. (Penal Code) with effect from January 01, 2006 (Čentéš et al., 2016). The so called "Front-end" type of home confinement was enacted in the Slovak legislation upon the Penal Code amendment dated January 01, 2006 that can be considered an alternative sanction to the sanction of imprisonment for less serious criminal acts, such as those resulting from the law diction expressed in $\S$ 53 clause 1 of Penal Code, to which the home confinement penalty can be awarded to offence perpetrator in duration for up to two years. Thus, we can state that this type of sanction cannot be awarded in case of crime commitment. Pursuant to $\S 34$ clause 6 of Penal Code, 2nd sentence, the Court of Justice must award the sanction of imprisonment for a criminal act with upper imprisonment 
limit exceeding five years, we can conclude that the alternative sanction is subject to certain limitations also in case of offences.

Provision of $\S 53$ clause 1 of the Penal Code regulates the terms of home confinement penalty awarding that must be fulfilled cumulatively. As stated above, the first condition stipulates that the home confinement penalty can be awarded only for offences. ${ }^{3}$ Awarding the home confinement penalty, the court of justice must take in account evaluation criterions related to the nature and importance of the offence committed, and also the perpetrator, representing the second basic condition. In case of offences, the court of justice makes an assessment of the criminal act commitment method, its consequences, circumstances of the act commitment, the blame rate and perpetrator's motive. Primarily, the court of justice should consider the nature of the criminal activity since awarding the home confinement penalty was probably undesirable in certain cases of home violence and criminal acts against family and youth, as constituted in the III. head of special section of the Penal Code (Romža et al., 2018). In evaluating a perpetrator, the court of justice takes into account especially personal and family conditions but proprietary conditions of the perpetrator should be neither neglected and, last but not least, future perpetrator's prognosis and his/ her re-socialization possibilities - correction possibilities should be considered. The third condition representing the essence of home confinement penalty corresponds to the written promise of the perpetrator declaring that he/ she shall stay in the determined address and provide required cooperation during control. The fourth requirement of such sanction award represents fulfillment of control by technical means examined by the court of justice before awarding an alternative sanction in the form of a home confinement penalty. Control of sanction execution by technical means is stipulated in a special law dealing with control of certain sanction execution by technical means. ${ }^{4}$ Control of home confinement penalty execution by technical means can be undoubtedly considered innovation in relation to control of sanction execution in general.

The content of home confinement penalty resulted from $\S 53$ clause 2 of Penal Code, to which a sentenced person is obliged to stay in his/ her residence including adjacent premises, to live a respectful life and to withstand control by technical means during period of home confinement penalty execution during the time period determined by the court of justice. Speaking of uncertainty of legislation, the court of justice deciding on home confinement penalty should specify the exact place of home confinement penalty in the verdict where the sentenced person shall stay, since currently it is a common praxis that a sentenced person can have permanent stay in the place other than he/she really stays in; also he/ she could own more real-estates and therefore the sanction execution place should be exactly specified. ${ }^{5}$ The judges should also specify exact time in the verdict when the sentenced person shall stay in the residence. Judicial praxis demonstrated that obligation to stay in the residence applies to the weekly working days and out of the working time within approx. 7:30 PM - 06:00 AM. To ensure that the sentenced person runs a proper life during the home confinement penalty execution, the court of justice is authorized to inflict restrictions or obligations stated in $\S 51$ clause 3 and clause 4 of the Penal Code.

The maximum length of sanction that a perpetrator can be sentenced by the court of justice to the home confinement penalty refers currently to two years pursuant to the Penal Code in effect ${ }^{6}$. If the sentenced person fails to fulfill obligations imposed by the court of justice, and restrictions resulting from the home confinement penalty, the court of justice shall change the home confinement penalty or a part of it to imprisonment. $\S 53$,clause 5 of the Penal Code stipulates the way of changing the home confinement penalty to unconditional imprisonment in proportion $1: 1$, following prior hearing of the sentenced person, in the form of a resolution passed by the court of justice at public proceedings. It means that one pending day of the home confinement penalty shall correspond to one day of imprisonment and the court of justice shall decide on the way of such imprisonment.

\footnotetext{
${ }^{3}$ Act No. 300/2005 Coll. - Penal Code as amended ( $\$ 53$ clause 1$)$.

${ }^{4}$ Act No. 78/2015 Coll. on Control of Execution of Certain Verdicts by Technical Means as amended.

${ }^{5}$ Interpreting the term ,residence“ follow $\S 122$ clause 5 of Penal Code No. 300/2005 Coll., to whichresidence shall be interpreted as a house, apartment or other premises serving to habitation, and other adjacent premises and lands that must be locked in order to be considered a part of residence.
}

${ }^{6}$ See $\S 53$ clause 1 of Pena Code No. 300/2005 Coll.as amended. 
Amendment of the Penal Code that became effective on January 01, 2016 introduced the institute of change of the remaining sentence to imprisonment in $\S 65 \mathrm{a}$ of Penal Code to home confinement penalty also called "Back-end" as another type of home confinement penalty, an alternative to parole. The essence of the "Back-end" type of home confinement penalty lays in unconditional sentencing to imprisonment that will change to parole in the form of home confinement penalty after the passing of a certain part of the imprisonment.

$\S 65 a$ of the Penal Code contains a rather detailed formulation of the terms at which the court of justice has the right to change the rest of imprisonment period to the home confinement penalty. As stated above, the rest of/ pending imprisonment period shall change and it is a requirement of unconditional sentence for imprisonment change to the home confinement penalty, cited in item c), § 65a clause 2 of the Penal Code. Before the effective date of the Penal Code amendment (February 20, 2019), the cited requirement wording stipulated that the pending imprisonment period shouldn't exceed two years. It was based on $\S 53$ clause 1 of the Penal Code and resulted from the upper imprisonment limit, since it would be illogical and unacceptable to change the imprisonment sanction to the home confinement penalty in longer duration as allowed by the cited provision (Ivor et al., 2016). Despite of such interpretation, the lawmaker enforced the change of requirement pursuant to $\S 65$ a clause 2 item c) in case of the remaining imprisonment period not exceeding three years. ${ }^{7}$ If the imprisonment sanction is changed to the home confinement penalty in this case (the remaining imprisonment of 3 years) pursuant to the law in determined 1:1, such change would result in the home confinement penalty in duration of three years that we consider a illegally levied sanction that breaches the maximum upper limit of the home confinement penalty ( 2 years).

The home confinement penalty is aimed at pointing to perpetrator's correction, since the sanction execution is associated with various re-socialization programs focused on the perpetrator's personality, and the sentenced person is not deprived of social and emotional bonds.

Despite of all of the positive aspects of the home confinement penalty enlisted herein, we should state that it is the least awarded sanction as resulting from the statistics of the Slovak Ministry of Justice. In 2015, home confinement penalty was awarded 18 times and 23 times in 2016. The average frequency has been affected by only 14 home confinement penalty awards in 2017 but again 20 awards in 2018, which however is hard to define as a satisfactory number. ${ }^{8}$

There are a few reasons for the rarity of the awarded type of sanction. As stated above, the possibility to check the sanction execution with technical means represents one of the terms of the home confinement penalty awarding. The court of justice must obligatorily examine the terms of sanction execution when awarding the home confinement penalty, thus the court must primarily examine the availability of required technical means (limited availability), technical equipment (GPS signal availability, power supply connection, fixed phone connection and location of home monitoring station. Such examination of the conditions is very demanding for the court of justice and hence the tendency to award more comfortable sanctions (for the court). It would be more appropriate when probation and mediation officers examined the technical background and report to the court of justice on possibilities of the home confinement penalty award to a particular accused person.

Here we encounter further application problems: only 98 persons perform as probation and mediation officers at particular courts of justice in the Slovak Republic. These officers have to monitor fulfillment of duties and restrictions pursuant to $\S 51$ clause 3,4 of the Penal Code that can be ordered to a sentenced person in relation to the home confinement penalty, along with other competences, but what is of utmost importance, probation and mediation officers check the technical means and this duty is called electronic monitoring ${ }^{9}$, which is obligatory within the home confinement penalty. Accordingly, a person sentenced to the home confinement penalty should enter the process of resocialization upon very close collaboration with probation officers. For illustration purposes only, we have to state that the justice system has current capacities to concurrently monitor 2,000 persons

\footnotetext{
${ }^{7}$ See $\S 65$ a clause 2 item ) c of Penal Code No. 300/2005 Coll. as amended.

${ }^{8}$ Statistical Yearbook of the Slovak Ministry of Justice available on Internet: www.justice.gov.sk.

${ }^{9}$ Adoption of Act No. 75/2015 Coll. on Check of Implementation of Some Decisions by Technical Means as amended resulted from project ESMO whose implementation started on Apr 28, 2014 under auspices ofthe Slovak Ministry of Justice.
} 
subject to electronic monitoring, but the capacity can be increased. Thus, if electronic monitoring is used exclusively for monitoring of the awarded home confinement penalty, a single officer would be in charge of approx. 20 persons being monitored, taking in account such a demanding work comprising of installating and uninstalling the technical means, recording, reporting and attending the incidents within control execution, checking of accessibility and proper operation of technical equipment. ${ }^{10}$ The number of assigned and completed probations in particular regions, related to the home confinement penalty in 2017, demonstrates the demanding nature of the agenda fulfillment resulting from the Electronic Monitoring Act - see in Table 1.

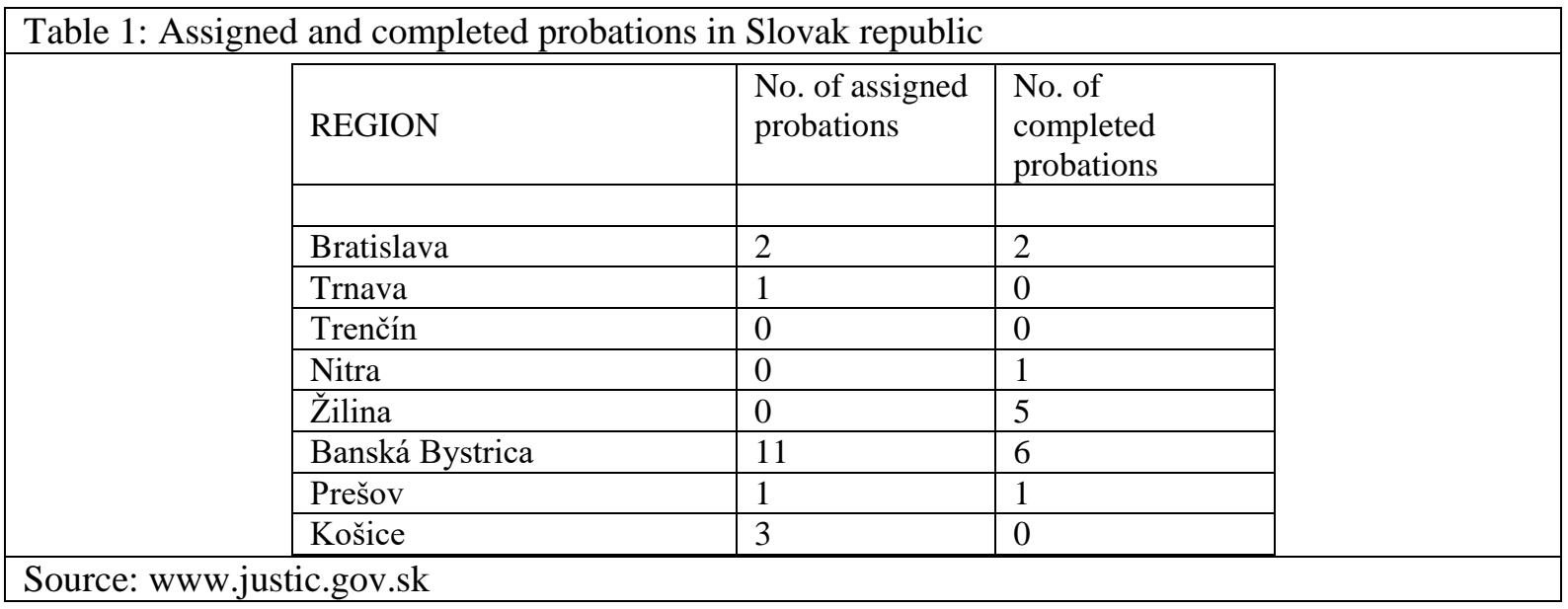

\section{Electronic monitoring}

Home imprisonment is also known as electronic monitoring or home detention. It is a legal term used to define a sanction imposed pursuant to law on a person that a committed crime and has been sentenced to stay at home instead of unconditional imprisonment in jail. Electronic monitoring represents a substantial part of penal systems worldwide, applied across all criminal proceedings stages from the preparation proceeding including proceedings in front of the Court, and also in execution proceedings. Electronic monitoring is a technical mean used by the law enforcement bodies, aimed at increasing the effectiveness in the area of perpetrator's movement monitoring for purposes of criminal proceedings and instant check of his/ her restricted movement, and also monitoring of all bans imposed.

Influenced by the penal policy development trends especially in the area of punishment and by penal proceedings modernization, the electronic system of persons monitoring has been enacted in the Slovak legislation and law order. While the system had been considered already in re-codifications, in particular in case of technical check in relation to established home imprisonment sanction, the system was implemented much later. It was enacted in the legislation upon adopted Act No. 78/2015 Coll. on Control of Certain Decisions Execution by Technical Means as amended (hereinafter "Act No. 78/2015 Coll."). The Act became effective on January 01, 2016 and the Electronic System of Persons Monitoring was established in Slovakia on the same date (Jecková, 2018). Act No. 78/2015 Coll. regulates technical means, their terms of use and the course of control.

Electronic monitoring represents the system of monitoring the observance of certain bans, restrictions and orders, as well as sanctions and certain protection measures as the forms of penal law sanctions. Pursuant to regulation in effect, we distinguish six types of monitoring where different types of technical means are used in each type of monitoring (Tittlová, 2018). Technical means operating cost is borne by the state and partly by the monitored person. Amount of his/her share is determined in the executive command. Technical means are the state property connected to a so-called central monitoring system. It is this that allows for the check of the detainment regime observance through signals transmitted by technical means, and the record of security and operating incidents (Klátik, 2018).

\footnotetext{
${ }^{10}$ See $\S \S 17-22$ Act No. $75 / 2015$ Coll. on Control of Certain Decisions Execution by Technical Means as amended.
} 
Technical means can be used in relation to proprietary law institutes (home imprisonment sanction; change of imprisonment sanction to home imprisonment sanction; sanction of restricted stay; sanction of restricted attendance of public events; protection supervision; probation supervision in case of conditional postponing of imprisonment sanction; probation supervision in case of parole;), and in relation to procedural law institutes (conditionally suspended criminal prosecution; detention replacement by probation and mediation officer). Despite of the broad application of technical means in the area of penal law, possibilities of their further use have been still identified.

Legislations of Austria, Switzerland, the Czech Republic, Norway, Scotland, Great Britain, Belgium, the Netherlands, Canada, USA, Australia, New Zealand, South Africa, Singapore and Brazil allow the same or similar control system by technical means. Active and passive monitoring systems represent two basic types of electronic monitoring of the sentenced people. Active monitoring systems allow for non-stop monitoring of a sentenced person and passive monitoring systems require from the sentenced person to call in to report themselves on pre-determined intervals (Strémy and Klátik, 2018). Different technical means are use in various world countries.

\section{Proposed legal regulation of the Home Confinement Penalty - de lege ferenda proposals}

Within the criminal policy, namely punishment, the proposal of an extended application of electronic monitoring/ technical means as such was adopted by the State Administration central office. For this purpose, the Slovak Ministry of Justice prepared the draft amendment of the Penal Code that directly amended the Penal Code and indirectly amended the Penal Order, Act on Probation and Mediation Officers, and Act on Legal Entity Criminal Liability (hereinafter the "draft amendment"). The draft amendment extends the regulation on the application of technical means to supervise the execution of certain decisions made within criminal proceedings, including the supported application of alternative sanctions. The draft amendment of the Penal Code logically corrected material- legal regulation of the terms of the home confinement penalty awards.

The first principal change relates to the maximum assessment of the home confinement penalty, i.e. determination of the upper limit of such a penalty duration. The two-year upper limit should be doubled, thus the maximum duration of the home confinement penalty would correspond to four years. Another principal change is associated with this penalty duration, namely specification of the group of criminal acts that could be punished with the home confinement penalty. Considering the original group of offences with upper penalty duration limit of max. 5 years, possibility of home confinement penalty expansion to criminal acts has been proposed according to the draft normative wording to which the court of justice can award the home confinement penalty for a crime that is subject to an imprisonment penalty with an upper limit not exceeding ten years, pursuant to the special act regulation, provided that the duration of the awarded home confinement penalty shall not be shorter than the duration of imprisonment penalty that could be awarded by the court of justice (draft wording of $\S 53$ clause 2 of Penal Code). The category of crimes that the court of justice will have the right to award the home confinement penalty for shall be subject to the upper limit of the imprisonment penalty stated in the special section of the Penal Code and shall not exceed ten years. Concurrently, the duration of awarded home confinement penalty shall not be shorter than duration of the imprisonment penalty that could be awarded by the court of justice for a particular criminal act.

The reasoning report indicates that it will result in limiting the court of justice awarding the home confinement with duration of imprisonment penalty that could be awarded by the court of justice for a particular criminal act and that shall not exceed a 4-year limit (maximum duration of the home confinement penalty). Pursuant to the draft amendment, the home confinement penalty could be awarded for all crimes with an upper limit of imprisonment penalty not exceeding ten years in case of the act that can be punished with a maximum 4-years of imprisonment pursuant to the Penal Code, applying thereto also provisions on possible reduction of the shortest criminal duration (e.g. extraordinary penalty reduction pursuant to $\S 39$ of the Penal Code). Applying a grammatical and logical interpretation, we can conclude that home confinement penalty shouldn't be shorter than the imprisonment penalty awarded for a particular criminal act but it can be longer than the imprisonment penalty awarded for particular criminal act, maximum up to four years (due to the maximum duration).

If current legislation assesses the nature and seriousness of the committed crime within fulfillment of normative terms (as well as perpetrator's person and conditions), then the proposed legislation must 
reflect the above stated changes and assess the seriousness aspect of the committed criminal act. We suppose that this supports material perception of the criminal act in this provision that is natural in case of offences, considering their legal regulation and mainly adverse specification in $\mathrm{v} \S 10$ clause 2 of the Penal Code, nevertheless it may be confusing in the case of a formal crime category. We should add that such material understanding such as a social harm will be reflected only in the area of punishment, penalty type selection and its duration (and in no case in the criminal act punishability).

Material- legal regulation has been extended by a new institute of conditional parole from home confinement penalty (new provisions of $\S 68 \mathrm{a}$ and $\S 68 \mathrm{~b}$ of Penal Code). It is an institute of a facultative nature that the court of justice could apply upon meeting certain formal and material requirements. Formal requirement represents $50 \%$ of the awarded home confinement penalty and concurrent material requirement stipulates that the sentenced person proved no need for continued execution of such penalty in the form of lifestyle led at the time of home confinement.

In the case of conditional home confinement penalty parole, the court of justice shall obligatorily determine up to a two-year probation period with no minimum limit. The determined probation period is an obligatory part of the court verdict on the conditional home confinement penalty parole and the probation period shall not be shorter than the remaining part of the home confinement penalty. Thus, the probation period shall be longer than the remaining part of the home confinement penalty but maximum up to two years (i.e., pending duration of the penalty must be of maximum a two-year duration, logically, since the maximum duration of the home confinement penalty refers to four years and conditional parole is formally conditioned with $50 \%$ of penalty execution, i.e. two years). The law amendment exactly determines also the commencement of probation period lapsing - probation period shall start to lapse on the day following the day of the court verdict effectiveness on the parole. The court of justice can impose reasonable restrictions and obligations to the sentenced person with conditional home confinement penalty parole, as stated in $\S 51$ clause 3 and 4 of the Penal Code aimed at making him or her to run a proper life. Imposition of reasonable restrictions and obligations is of facultative nature and doesn't condition the decision on the conditional home confinement penalty parole. The court of justice shall obligatorily order probation supervision except in the obligation to indemnify for damage caused by a criminal act or the payment of a debt or pending alimony.

If a person sentenced subject to conditional home confinement penalty parole ran a proper life during the probation period and didn't breach the imposed restrictions and obligations, the court of justice shall declare his/ her conformance. Declared conformance of the sentenced person shall correspond to completion of the penalty awarded, otherwise (if not conformed) it shall be decided after or during the probation period that the remaining part of the home confinement penalty shall be transformed to unconditional imprisonment in duration according to the following scheme: One pending day of the home confinement penalty shall equal to one day of unconditional imprisonment. Concurrently, the court of justice shall decide on the method of penalty execution (external differentiation).

If the court of justice declared conformance of the sentenced person, it shall be supposed that the penalty was completed on the day of excused remaining home confinement penalty effectiveness. Thus, the so called law function is regulated here that the penalty was completed, coming into effect on the day of the effective date of the excused remaining home confinement penalty. While the reasoning report states that the fiction effect is important especially for the purpose of determining the commencement of period for penalty extinguishing pursuant to $\S 92$ of the Penal Code; referring to the wording of clause $2 \S 92$ of the Penal Code, the home confinement penalty award is ex lege extinguished upon the penalty completion with no period lapsed, thus it is not necessary to determine the commencement date through the law function.

Equally, it is believed that the home confinement penalty was completed on the day when the decision of conditional home confinement penalty parole became effective, provided that the court of justice had not ordered the execution of the remaining penalty by the person sentenced within a year from lapsed probation period without the sentenced person's blame, or if the court of justice had not decided so within two years from the lapsed probation period without the sentenced person's blame if the sentenced person has been subject to criminal prosecution for another criminal act committed during the probation period. Otherwise said, the court of justice must issue a testimony of "nonconformance" within a year the from lapsed probation period (or within two years from the lapsed probation period if the sentenced person has been subject to criminal prosecution for another criminal 
act committed during the probation period), otherwise a function of the sentenced person's conformance shall apply.

In relation to the above stated law amendment on the conditional home confinement penalty parole (proposed provisions of $\S 68 \mathrm{a}$ and $\S 68 \mathrm{~b}$ of Penal Code) legal requirements of the home confinement penalty parole explanation has been proposed in the Penal Code Procedural regulation which stipulates that the conditional home confinement penalty parole institute pursuant to proposed $\S 435 \mathrm{~b}$ of the Penal Order, introducing material-law regulation of the conditional home confinement penalty parole as analogy to the provisions applicable to other penalties, which has been absent so far and is partly included in the provisions of current $\S 435$ clause 4 of the Penal Order. It is an institute of facultative nature to which the court of justice can decide on the home confinement penalty parole if the person sentenced suffers incurable serious illness or incurable mental illness. The court of justice shall decide in the form of passed resolution that is subject to permitted legal remedy - complaint with suspension effect. Incurable and life-threatening illness is such an illness whose health consequences result in the affected person's death regardless of the illness duration. Incurable and life-threatening mental illness doesn't cause the affected person's death but incapability to perceive the surrounding world and respond thereto in the way that is adequate for mentally healthy individual. With its structure and contents, the proposed $\S 435 \mathrm{~b}$ corresponds to a provision of $\S 413$ clause 2 and 3 of the Penal Order, regulated by the institute of home confinement penalty parole. Accordingly, introduction of the legal definition of the term "mental illness" or "mental disorder" should be re-considered and amended in the Penal Code. The border between the two terms has been diminished in medicine in the last few years; nevertheless they should be differentiated since they condition the application of material- law and procedural institutes and as such, they should be legally defined directly in the Penal Code provisions within the interpretation of terms.

A draft amendment shall definitely cause an increased frequency of alternative penalties awarding, especially the home confinement penalty. As stated above, the home confinement penalty could be awarded so far only for offences, but the new regulation will permit award of such a penalty also for crimes, i.e. more serious criminal act types. The expanded group of criminal acts shall logically cause expansion of possibilities to award such a penalty.

On the other hand, if the alternative penalty frequency increases, it will concurrently cause an increase of applications of the so called institute of preliminary investigation pursuant to the Act on Probation and Mediation Officers to be performed by the stated officers. The agenda of probation officers shall increase but not their headcount. The need for increased headcount of probation officers has been declared for a long time and claimed by these probation officers themselves. So far, we reported only internal structural changes but not the headcount increase. If there are practical problems present currently in relation to the probation officers' headcount in the situation of insufficiently applied alternative penalties, we can logically expect the increase of application problems. Such a situation might prolong the criminal proceedings unnecessarily. On the procedural level, the draft amendment of law can determine the declaration of guilt pursuant to $\S 257$ clause 1 item b) of the Penal Order, especially in cases that could be subject to sentencing to imprisonment for a period up to four years.

\section{Conclusion}

Finally, we should comment also rather upon the complicated nature of the home confinement penalty awarding in the case of crimes (despite of legislation using the term ,criminal acts"). The draft amendment stipulates that the home confinement penalty shall not be shorter than the imprisonment penalty that could be awarded for such a crime. First of all, the court of justice will have to conclude what duration of imprisonment would be awarded. Subsequently, the particular duration of the home confinement penalty shall depend on the theoretical duration of imprisonment. Accordingly, an alternative relation shall apply; i.e. the home confinement penalty as an alternative of imprisonment penalty since finally another penalty shall be executed than the imprisonment but the nature of the direct alternative of the home confinement penalty to a short-term imprisonment shall cease. This idea is supported by the fact that maximum duration of the home confinement penalty should refer to four years. Thus, a question emerges whether a four-year unconditional imprisonment penalty still refers to a short-term penalty. Does a four-years taking home confinement penalty represent an alternative to four-year unconditional imprisonment penalty or only an alternative method of the penalty execution, or more broadly said, another form of penalty execution? 


\section{Discussion}

Resulting from common legislation development in the common state and the same law principles that penal legislation was built on, the home imprisonment sanction regulation in the Czech Republic described in $\S \S 60-61$ Act No. 40/2009 Coll. (Penal Code) equals to that in Slovakia. The Court of Justice can sentence an offence perpetrator to home imprisonment sanction in the Czech Republic for two years, provided that such a sanction is sufficient, taking in account the nature and seriousness of the committed crime, as well as the perpetrator's personality and conditions. The perpetrator must swear in writing that he/she shall stay at home during the determined time and cooperate during control. The Ministry of Justice or an established organizational unit shall provide for home imprisonment sanction control in cooperation with the Probation and Mediation Services via an electronic control system allowing for the detection of the sentenced person's movement, or the Probation and Mediation Services in the form of a performed control (Romža et al., 2018).

Referring to the historical development, the Slovak penal regulation of home imprisonment sanction is close to that established in Hungary. The Hungarian regulation distinguishes between alternative sanctions and alternative sanction methods. Alternative sanction methods in Hungary include electronic monitoring. Electronic monitoring was enacted on April 01, 2015. It was presented as an institute of monitoring of sentenced persons released on parole and it can be applied if the sentenced person is detained in a so called "re-integration facility". This institute can be also applied in cases of first-time perpetrators who face a sentence of imprisonment for a maximum of three years (Nagy, 2015).

The home imprisonment sanction originated overseas. It was used for the first time in the USA in the 1980s, thus it has had a long tradition in overseas countries (Sčerba, 2011). Considering such a longterm existence and tradition of home imprisonment sanction use as an alternative sanction, we can definitely answer questions related to home imprisonment sanction imposition effectiveness and possibilities of its modifications.

According to the above stated facts, it is apparent that V4 countries (the Czech Republic, Hungary and Slovakia) refer to the countries with almost no tradition of the home imprisonment sanction and electronic monitoring that would give room for orientation within the subject matter and the possibility to answer fundamental questions related to electronic monitoring, namely: Does electronic monitoring affect recidivism after the electronic monitoring period has concluded? Does electronic monitoring affect offender criminal behavior during the monitored period? Aside from recidivism impacts, what is the financial impact of operating electronic monitoring? Does electronic monitoring allow more people to be dealt with more severely than they would have been had it not been used? (Nellis et al., 2013).

In Slovakia, the lawmaking authority amended the Penal Code in relation to proprietary law terms of home imprisonment sanction imposition and the efforts to expand possibilities of electronic monitoring application as declared herein, without any research and relevant grounds. Accordingly, we suppose that such efforts cannot be named otherwise but arbitrariness, even if we take in account the fact that the surrounding countries have never declared such efforts. On the contrary, they tried to maintain and accentuate the alternative nature of the home imprisonment sanction in relation to standard imprisonment as resulted from the quoted home imprisonment sanction regulation of the particular countries specified above.

At the end of the discussion, the authors adhere to the statement that the Slovak regulation of home imprisonment sanction is sufficient in its current form, copying fundamental principles of restorative justice, taking into account the regulation in this area by the surrounding countries; and the lawmaker should focus its efforts on possibilities of electronic monitoring utilization upon the terms allowed by the legislation in effect, instead of changing the proprietary law terms of home imprisonment sanction imposition without a real basis.

\section{Acknowledgment}

This article is an output of the grant project APVV-16-0362 Privatization of Criminal Law - the substantive, procedural, criminological, organizational and technical aspects. 


\section{References}

Act No. 550/2003 Coll.on Probation and Mediation Officers as amended

Act No. 300/2005 Coll. - Penal Code as amended

Act. No. 301/2005 Coll. - Criminal Procedural Act as amended

Act No. 78/2015 Coll. on Control of Execution of Certain Verdicts by Technical Means as amende

Čentéš, J. et al. (2016). Trestné právo procesné. Osobitná čast' [Procedural Criminal Law. Special section]. Šamorín, SVK: Heuréka.

Dôvodová správa k návrhu novely Trestného zákona [The reasoning Report on the Draft Amendment to the Penal Code]

Gábriš,T. and Jáger, R.(2016). Nové metodologické postupy pri skúmaní trestných činov vo vel'komoravskom práve [New methodological approaches in examining of offences in law in Great Moravia].Nové trendy v práve 1 [New trends in Law 1], Banská Bystrica, SVK: Publishing of Matej Bel University, 101-153.

Gábriš, T. and Jáger, R. (2018). Dispute resolution in Great Moravia and the role of Posluch. Zeitschrift der Savigny-Stiftung für Rechtsgeschichte, Germanistische Abteilung, 135 (1), 325-343.

Gábriš, T. and Jáger, R. (2019). Back to Slavic Legal History? On the Use of Historical Linguistic in History of Slavic Law. Frühmittelalterliche Studien, 53 (1), 32-45.

http://www.justice.gov.sk/Stranky/default.aspx

https://esmo.gov.sk/web/esmo/metodiky-a-informacne-materialy

Ivor, J. et al. (2016). Trestné právo hmotné. Všeobecná čast’ 1 [Material Criminal Law. General Section 1]. Bratislava, SVK :Wolters Kluwer.

Jecková, A. (2018). Elektronický systém monitorovania osôb [Electronic System for Monitoring People]. I. KOŠICKÉ DNI TRESTNÉHO PRÁVA - Perspektívy vývoja európskeho trestného práva [I. KOSICE DAYS OF CRIMINAL LAW Perspectives on the Development of European Criminal Law], Košice, SVK: Pavol Jozef Safárik University, 261-262.

Klátik, J. (2018). Uplatňovanie restoratívnej justície a elektronického monitoringu na Slovensku a vo vybraných štátoch Európskej únie [Application of Restorative Justice and Electronic monitoring in Slovakia and Selected Countries of the European Union]. I. KOŠICKÉ DNI TRESTNÉHO PRÁVA - Perspektívy vývoja európskeho trestného práva [I. KOSICE DAYS OF CRIMINAL LAW - Perspectives on the Development of European Criminal Law], Košice, SVK: Pavol Jozef Safárik University, 273.

Klimek, L. (2017a).Mutual Recognition of Judicial Decisions in European Criminal Law. Cham, DEU: Springer.

Klimek, L. (2017b).Základy trestného práva Európskej únie[Fundamentals of European Union Criminal Law]. Bratislava, SVK: Wolters Kluwer.

Nagy, A. (2015). Release from prison. EUROPEAN INTEGRATION STUDIES, (11), 15-24.

Nellis, M. et al. (2013).Electronically monitored punishment: international and critical perspectives. New York, USA:Routledge.

Romža, S. et al. (2018).Alternatívne spôsoby výkonu trestov[Alternative imprisonment forms]. Košice, SVK: Šafárik Press UPJŠ in Košice.

Strémy, T. and Klátik, J. (2018).Alternativne tresty [Alternative Sanctions]. Bratislava, SVK: C. H. Beck.

Sčerba, F. (2011). Alternativní tresty a opatření v nové právní úpravě [Alternative Sanctions and Measures in the New Legislation]. Praha, CZ: Leges.

Tittlová, M. (2018). Trestnoprávne sankcie ukladané fyzickým osobám [Criminal SanctionsImposed on Natural Person]. Bratislava, SVK: Wolters Kluwer. 